\title{
Soft Tissue Sarcoma pT0 TNM Finding v7
}

National Cancer Institute

\section{Source}

National Cancer Institute. Soft Tissue Sarcoma pTO TNM Finding v7. NCI Thesaurus.

Code C88453.

Soft tissue sarcoma with no evidence of primary tumor. (from AJCC 7th Ed.) 